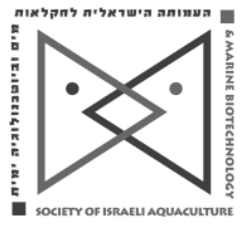

The IJA appears exclusively as a peerreviewed on-line Open Access journal at http://www.siamb.org.il Sale of IJA papers is strictly forbidden.

\title{
Effects of Dietary Pelargonium sidoides Extract on Growth Performance in Common Carp, Cyprinus carpio
}

\author{
Funda Turan*, Armağan Gezer, Yasemin Bircan-Yildirim
}

Department of Aquaculture, Faculty of Fisheries an Aquaculture, University of Mustafa Kemal, 31200 Iskenderun, Hatay, Turkey

(Received 23.2.10, Accepted 5.4.10)

Key words: Pelargonium sidoides, common carp, Cyprinus carpio, growth

\begin{abstract}
The effects of graded dietary supplementation of Pelargonium sidoides extract on growth performance, feed utilization, and body composition in common carp, Cyprinus carpio, were preliminarily evaluated. Fish $(0.67 \pm 0.05 \mathrm{~g})$ were fed experimental diets containing $0,1,3$, or $5 \mathrm{ml} / 100 \mathrm{~g} P$. sidoides extract for 90 days. Growth rate significantly $(p<0.05)$ increased in carp fed supplemented diets. The specific growth rate ranged from $2.87 \pm 0.09$ in the control to $3.41 \pm 0.11$ in fish fed the diet supplemented with $5 \mathrm{ml} P$. sidoides. The feed conversion ratio, protein efficiency ratio, and apparent net protein utilization were significantly better in groups fed diets with 3 or $5 \mathrm{ml} P$. sidoides extract than in the control or $1 \mathrm{ml}$ group. The highest protein content $(19.65 \%)$ was obtained with $3 \mathrm{ml}$ supplementation. The present study shows that $P$. sidoides extract has a positive effect on carp growth and feed utilization with no apparent effects on health status.
\end{abstract}

* Corresponding author. Tel.: +90-326-6141866, fax: +90-326-6141877, e-mail: turanfunda@yahoo.com (fturan@mku.edu.tr) 


\section{Introduction}

Many herbs have long been used as foods or folk medicines to prevent or cure disease. As organic and side-effect-free alternatives to standard medicines, herbal extracts are increasingly being viewed as practical safe alternatives to synthetic pharmaceutical agents for treating illness. Herbal fish diets can promote growth performance (Kim et al., 1998, 2000; Lee et al., 2004; Turan, 2006; Ji et al., 2007a,b) and survival (Lee et al., 2004), increase stress tolerance (Ji et al., 2007a, 2009), serve as feeding attractants (Harada, 1991), enhance immune system efficiency (Kwon et al., 1999; Jian and Wu, 2003; Sivaram et al., 2004; Abutbul et al., 2005; Selvaraj et al., 2005; Bhuvaneswari et al., 2006; Ji et al., 2007b; Dibyendu et al., 2008; Bai et al., 2009), and even produce all-male populations (Turan and Çek, 2007).

Pelargonium sidoides extract is one of the most important medicinal herbs used in folk medicine by the South African native population. It is used in traditional medicine to cure infectious respiratory diseases including tuberculosis and is successful in modern phytotherapy in Europe (Haidvogl et al., 1996). A diet based on $P$. sidoides extract improved growth and increased the protein level in freshwater crayfish (Turan et al., in press). In the present study we examined whether dietary $P$. sidoides extract enhances growth performance, feed utilization, and carcass composition in common carp, Cyprinus carpio.

\section{Materials and Methods}

The experiment was carried out at the Aquaculture Research Unit of the Mustafa Kemal University. Common carp, Cyprinus carpio $(0.67 \pm 0.05 \mathrm{~g})$, were stocked in twelve 100-I aquaria $(0.8 \times 0.4 \times 0.4 \mathrm{~m})$ at a density of 15 fish per aquarium. The aquaria were aerated, supplied with continuously flowing water $(2 \mathrm{l} / \mathrm{min})$, and temperature controlled $\left(24 \pm 1^{\circ} \mathrm{C}\right)$. The photoperiod was maintained at $12 \mathrm{~h}$ light: $12 \mathrm{~h}$ dark. Water temperature was measured daily with a thermometer and averaged $24 \pm 1^{\circ} \mathrm{C}$. Oxygen content was measured daily with a model 55 YSI oxygen meter (Yellow Springs Instruments $\mathrm{Cy}$. Ohio) and averaged $5.76 \pm 0.35 \mathrm{ppm}$. $\mathrm{pH}$ was determined weekly with an Accumet pH meter (model 915, Fisher Scientific, Pennsylvania). Weekly water samples were collected and ammonia nitrogen $\mathrm{N}-\mathrm{NH}_{4}$ (Nessler method), and nitrite nitrogen $\mathrm{N}-\mathrm{NO}_{2}$ (sulphanil method) were determined colorimetrically with a spectrophotometer. At $\mathrm{pH} 7.9 \pm 0.3$, the ammonia nitrogen content did not exceed $0.1 \mathrm{mg} \mathrm{N}-\mathrm{NH}_{4} / \mathrm{l}$ and nitrite nitrogen was not higher than $0.04 \mathrm{mg} \mathrm{N}-\mathrm{NO}_{2} / \mathrm{l}$.

Liquid $P$. sidoides extract (UMCA®, Dr. Willmar Schwabe Pharmaceuticals GmbH \& Co., Ettlingen, Germany; 1, 3, or $5 \mathrm{ml}$ extract/100 g diet) was mixed with a pulverized carp diet (45\% protein and $12 \%$ lipid, wet basis; PInar Co. Turkey), water $(450 \mathrm{ml} / \mathrm{kg}$ ) was added, and the mixture was extruded through a food grinder with a 2-mm diameter die. The control diet was also mixed with $450 \mathrm{ml}$ water/ $\mathrm{kg}$ diet. The extrusions were broken into small pieces and stored in a freezer until feeding. The diets were randomly assigned to triplicate groups of fish which were fed approximately $10 \%$ of their body weight daily, twice a day for 90 days. 
Mortality was recorded daily and fish in each aquarium were counted and weighed individually at bimonthly intervals after anesthetization for $2.5 \mathrm{~min}$ in water that contained tricaine methanesulphonate (TMS) at $0.4 \mathrm{~g} / \mathrm{l}$ and sodium bicarbonate as a buffer at $0.8 \mathrm{~g} / \mathrm{l}$. Fish were individually weighed and measured (total length) to the nearest $0.01 \mathrm{~g}$ and $0.01 \mathrm{~cm}$. Weight gain, feed conversion ratio, specific growth rate, survival, protein efficiency ratio (Bender and Miller, 1953), and apparent net protein utilization were calculated.

Fifteen fish were randomly chosen at the start of experiment, treated with an overdose of phenoxyethanol $(1.5 \mathrm{mg} / \mathrm{l})$, and stored at $-20^{\circ} \mathrm{C}$ for determination of body proximate composition. Five fish from each treatment were randomly chosen at the end of the feeding trial and analyzed for final whole body proximate composition (AOAC, 1990).

Data were subjected to one-way analysis of variance to determine if there were significant differences in weight gain and body composition. Differences were considered significant when $p<0.05$. Duncan test was used to compare the means when significant differences occurred (Norusis, 1993).

\section{Results}

After 90 days of rearing, growth of groups fed diets containing 3 or $5 \mathrm{ml} P$. sidoides $/ 100 \mathrm{~g}$ diet was significantly better than growth of groups fed the $1 \mathrm{ml}$ or control diet (Table 1). There were no statistical differences in survival. The feed conversion ratio, protein efficiency ratio, and apparent net protein utilization were significantly better in the groups fed the diets containing 3 or

Table 1. Growth performance and feed utilization in common carp (Cyprinus carpio) fed diets containing different concentrations of Pelargonium sidoides extract for 90 days.

Pelargonium sidoides $(\mathrm{ml} / 100 \mathrm{~g}$ feed)

\begin{tabular}{lccccc} 
& Initial & 0 (control) & 1 & 3 & 5 \\
\hline Wt gain (g) & - & $7.55 \pm 0.22^{\mathrm{a}}$ & $8.21 \pm 0.97^{\mathrm{a}}$ & $10.54 \pm 0.15^{\mathrm{b}}$ & $12.66 \pm 0.39^{\mathrm{c}}$ \\
SGR $^{1}$ & - & $2.87 \pm 0.09^{\mathrm{a}}$ & $2.83 \pm 0.19^{\mathrm{a}}$ & $3.36 \pm 0.10^{\mathrm{b}}$ & $3.41 \pm 0.11^{\mathrm{b}}$ \\
FCR $^{2}$ & - & $1.99 \pm 0.15^{\mathrm{b}}$ & $1.90 \pm 0.11^{\mathrm{b}}$ & $1.49 \pm 0.09^{\mathrm{a}}$ & $1.23 \pm 0.05^{\mathrm{a}}$ \\
PER $^{3}$ & - & $0.99 \pm 0.03^{\mathrm{a}}$ & $1.07 \pm 0.12^{\mathrm{a}}$ & $1.38 \pm 0.02^{\mathrm{b}}$ & $1.65 \pm 0.05^{\mathrm{c}}$ \\
ANPU $^{4}$ & - & $20.61 \pm 0.96^{\mathrm{a}}$ & $21.31 \pm 0.72^{\mathrm{a}}$ & $29.93 \pm 1.02^{\mathrm{b}}$ & $36.11 \pm 0.39^{\mathrm{c}}$ \\
Survival (\%) & - & $88.89 \pm 5.88$ & $93.33 \pm 3.85$ & $86.87 \pm 3.85$ & $91.14 \pm 2.22$ \\
\hline Chemical composition $(\%)^{5}$ & & & & \\
\hline Moisture & $73.54 \pm 0.34$ & $73.53 \pm 0.26$ & $74.02 \pm 0.31$ & $73.06 \pm 0.48$ & $73.02 \pm 0.86$ \\
Crude protein & $17.34 \pm 1.63$ & $17.44 \pm 0.34^{\mathrm{a}}$ & $17.21 \pm 0.38^{\mathrm{a}}$ & $19.65 \pm 0.44^{\mathrm{b}}$ & $19.57 \pm 0.57^{\mathrm{b}}$ \\
Crude lipid & $6.74 \pm 0.29$ & $6.77 \pm 0.42$ & $7.58 \pm 0.54$ & $7.02 \pm 0.70$ & $7.05 \pm 0.46$ \\
Ash & $0.95 \pm 0.05$ & $0.74 \pm 0.07$ & $0.89 \pm 0.15$ & $0.85 \pm 0.27$ & $0.87 \pm 0.12$ \\
\hline
\end{tabular}

Means in a row with different superscripts significantly differ $(p<0.05)$.

${ }^{1}$ Specific growth rate $(\%)=\left[\left(\ln W^{2}-\ln ^{1}\right) \backslash\left(T^{2}-T^{1}\right)\right] \times 100$, where $W^{1}$ and $W^{2}$ are the mean body weight when the first and second samples were taken $\left(\mathrm{T}^{1}\right.$ and $\left.\mathrm{T}^{2}\right)$

${ }^{2}$ Feed conversion ratio $=$ dry feed intake/wet wt gain

3 Protein efficiency ratio = live body wt gain/protein intake

${ }^{4}$ Apparent net protein utilization $(\%)=($ protein retained $/$ protein intake $) \times 100$

${ }^{5}$ Wet basis 
$5 \mathrm{ml} \mathrm{P}$. sidoides extract. Likewise, the protein contents of the groups fed the 3 or $5 \mathrm{ml}$ diets were significantly higher than of those fed the other diets. There were no significant differences in whole body moisture, lipid, or ash.

\section{Discussion}

The present work demonstrates that $P$. sidoides extract promotes growth and increases the protein level of common carp. The extract did not adversely influence survival, weight gain, or feed intake. The best growth rate and food conversion ratio were obtained with the $5 \mathrm{ml}$ diet. Likewise, pelleted feeds containing $2 \mathrm{ml} P$. sidoides extract per $100 \mathrm{~g}$ feed promoted growth efficiency in crayfish, Astacus leptodactylus (Turan et al., in press).

Although our results indicate that $P$. sidoides extract has a stimulatory effect on fish growth, gaps exist in the understanding of the mechanisms of action of $P$. sidoides extract in fish. Unknown factors in various medicinal herbs lead to favorable results in fish and shrimp trials (Kim et al., 1998). Medicinal herbs promote lipid metabolism, protein accumulation, and growth performance (Sivaram et al., 2004). Pelargonium sidoides is rich in photochemicals, vitamins, minerals, and amino acids that enhance the body's functioning and protect it against disease (Kolodziej et al., 2003). Polymeric polyphenols and coumarins have been identified as its principal ingredients (Kolodziej et al., 2003). Most coumarins have a methoxy functionality that is responsible for their antibacterial activity. Large amounts of gallic acid and methyl ester are the prominent immunomodulatory principles of $P$. sidoides (Kayser and Kolodziej, 1998). The root of $P$. sidoides contains phytopharmaceuticals. It may be these phytochemicals stimulate growth in common carp. Future research should concentrate on understanding the physiological mechanisms by which dietary $P$. sidoides extract improves growth in common carp.

The present study demonstrates that inclusion of $5 \mathrm{ml} P$. sidoides extract per $100 \mathrm{~g}$ diet has a positive effect on common carp growth performance with no apparent effects on health status. The study supports the palatability of $P$. sidoides extract in diets for increased growth rate. Further experiments might clarify whether specific components possess higher potency as appetite enhancers in fish. The practical implications of $P$. sidoides extract inclusion in aquafeeds include the potential for increasing feed intake. This would allow for faster fish growth, leading to improved production time.

\section{Acknowledgements}

This research was supported by the Scientific Research Foundation Unit of Mustafa Kemal University (08 M 1402).

\section{References}

Abutbul S., Golan-Goldhirsh A., Barazani O., Ofir R. and D. Zilberg, 2005. Screening of desert plants for use against bacterial pathogens in fish. Isr. J. Aquacult. - Bamidgeh, 57(2):71-80.

AOAC, 1990. Official Methods of Analysis. 15th ed. Association of Official Analytical Chemists, Arlington, Virginia, USA. 
Bai D.Q., Li R., Xing K.Z., Guo Y.J., Chen C.X., Qiao X.T., Mao H.T. and G.X. Zhu, 2009. In vitro antibacterial activity of herbal medicines and combinations of herbal medicines and antibiotics against Edwardsiella tarda. Isr. J. Aquacult. - Bamidgeh, 61(1):27-34.

Bender A.E. and D.S. Miller, 1953. A new brief method of estimating protein value. J. Biochem. 53:7.

Bhuvaneswari R. and C. Balasundaram, 2006. Traditional Indian herbal extracts used in vitro against growth of the pathogenic bacteria - Aeromonas hydrophila. Isr. J. Aquacult. - Bamidgeh, 58(2):89-96.

Dibyendu K., Siddhartha N.J., Bimal C.M. and T.K. Maiti, 2008. Effects of a glucan from the edible mushroom (Pleurotus florida) as an immunostimulant in farmed Indian major carp (Catla catla). Isr. J. Aquacult. -Bamidgeh, 60(1):37-45.

Haidvogl M., Schuster R. and M. Heger, 1996. Akute Bronchitis im Kintesalter-Multizenter-Studie zur Wirksamkeit und Vertraglichkeit des Phytotherapeutikums Umckaloabo. Z. Phytotherapy, 17(5):300-319.

Harada H., 1991. Attraction activities of herbal crude drugs for abalone, oriental weatherfish, and yellowtail. Nippon Suisan Gakkaishi, 57:2083-2088.

Ji S.C., Jeong G.S., Im G.S., Lee S.W., Yoo J.H. and K. Takii, 2007a. Dietary medicinal herbs improve growth performance, fatty acid utilization, and stress recovery of Japanese flounder. Fish. Sci., 73:70-76.

Ji S.C., Takaoka O., Jeong G.S., Lee S.W., Ishimaru K., Seoka M. and K. Takii, 2007b. Dietary medicinal herbs improve growth and some non-specific immunity of red sea bream Pagrus major. Fish. Sci., 73:63-69.

Ji S.C., Takaoka O., Lee S.W., Hwang J.H., Kim Y.S., Ishimaru K., Seoka M., Jeong G.S. and K. Takii, 2009. Effect of dietary medicinal herbs on lipid metabolism and stress recovery in red sea bream Pagrus major. Fish. Sci., 75:665-672.

Jian J. and $\mathbf{Z}$. Wu, 2003. Effects of traditional Chinese medicine on nonspecific immunity and disease resistance of large yellowcroaker, Pseudosciaena crocea (Richardson). Aquaculture, 218:1-9.

Kayser O. and H. Kolodziej, 1998. Antibacterial activity of extracts and constituents of Pelargonium sidoides and Pelargonium reniforme. Planta Medica, 63:508-510.

Kim D.S., Noh C.H., Jung S.W. and J.Y. Jo, 1998. Effect of Obosan supplemented diet on growth, feed conversion ratio and body composition of Nile tilapia, Oreochromis niloticus. J. Aquacult., 11:83-90.

Kim J.H., Moon Y.B., Jeong C.H. and D.S. Kim, 2000. Utilization of dietary Obosan. III. Growth of juvenile olive flounder, Paralichthys olivaceus. J. Aquacult., 13:231-238.

Kolodziej H., Kayser O., Radtke O., Kiderlen A. and E. Koch, 2003. Pharmacological profile of extracts of Pelargonium sidoides and their constituents. Phytomedicine, 10(suppl. 4):18-24.

Kwon M.G., Kim Y.C., Shon Y.C. and S.I. Park, 1999. The dietary supplementing effects of kugija, Lycium chinese, on immune responses of Nile tilapia, Oreochromis niloticus to Edwardsiella tarda. J. Fish. Pathol., 1:73-81. 
Lee K.J., Dabrowski K., Rinchard J., Gomez C., Leszek G. and C. Vilchez, 2004. Supplementation of maca (Lepidium meyenii) tuber meal in diets improves growth rate and survival of rainbow trout Oncorhynchus mykiss (Walbaum) alevins and juveniles. Aquacult. Res., 35:215-223.

Norusis M.J., 1993. SPSS for Windows Advanced Statistics, release 6.0. SPSS Inc., USA. 578 pp.

Selvaraj V., Sampath K. and V. Sekar, 2005. Use of glucan from Saccharomyces cerevisiae as an immunostimulant in carp: impact on hematology, phagocyte function, and infection with Aeromonas hydrophilla. Isr. J. Aquacult. - Bamidgeh, 57(1):39-48.

Sivaram V., Babu M.M., Immanuel G., Murugadass S., Citarasu T. and M.P. Marian, 2004. Growth and immune response of juvenile greasy groupers (Epinephelus tauvina) fed with herbal antibacterial active principle supplemented diets against Vibrio harveyi infections. Aquaculture, 237:9-20.

Turan F., 2006. Improvement of growth performance in tilapia (Oreochromis aureus Linnaeus) by supplementation or red clover (Trifolium pratense) in diets. Isr. J. Aquacult. - Bamidgeh, 58(1):34-38.

Turan F. and Ş. Çek, 2007. Masculinization of African catfish (Clarias gariepinus, Burchell, 1822) treated with Gokshura (Tribulus terrestris). The Israeli Aquacult. Bamidgeh, 59(4):224-229.

Turan F., Mazlum Y., Bircan Yildirim Y. and A. Gezer, in press. Use of dietary Pelargonium sidoides extract to improve growth and body composition of narrow-clawed crayfish Astacus leptodactylus Eschscholtz, 1823, juveniles. Aquacult. Res. 